\title{
An in silico investigation of phytochemicals as potential inhibitors against non-structural protein 1 from dengue virus 4
}

\author{
Iqra Qaddir', Arshia Majeed², Waqar Hussain ${ }^{3}$, Sajid Mahmood ${ }^{4}$, \\ Nouman Rasool ${ }^{\circledR *}$ \\ ${ }^{1}$ Department of Chemistry, University of Management and Technology, Lahore, Pakistan, \\ ${ }^{2}$ Medicare Health Services, Lahore, Pakistan, Pakistan, ${ }^{3}$ National Center of Artificial \\ Intelligence, Punjab University College of Information Technology, University of the Punjab, \\ Lahore, Pakistan ${ }^{4}$ Center for Professional Studies, Lahore, Pakistan, ${ }^{5}$ Department of \\ Informatics and Systems, University of Management and Technology, Lahore, Pakistan
}

\begin{abstract}
Dengue fever has emerged as a big threat to human health since the last decade owing to high morbidity with considerable mortalities. The proposed study aims at the in silico investigation of the inhibitory action against DENV4-NS1 of phytochemicals from two local medicinal plants of Pakistan. Non-Structural Protein 1 of Dengue Virus 4 (DENV4-NS1) is known to be involved in the replication and maturation of viron in the host cells. A total of 129 phytochemicals (50 from Tanacetum parthenium and 79 from Silybum marianum) were selected for this study. The tertiary structure of DENV4-NS1 was predicted based on homology modelling using Modeller 9.18 and the structural stability was evaluated using molecular dynamics simulations. Absorption, distribution, metabolism, excretion and toxicity (ADMET) along with the drug-likeness was also predicted for these phytochemicals using SwissADME and PreADMET servers. The results of ADMET and drug-likeness predictions exhibited that 54 phytochemicals i.e. 25 from Tanacetum parthenium and 29 from Silybum marianum showed effective druglikeness. These phytochemicals were docked against DENV4-NS1 using AutoDock Vina and 18 most suitable phytochemicals with binding affinities $\leq-6.0 \mathrm{kcal} / \mathrm{mol}$ were selected as potential inhibitors for DENV4-NS1. Proposed study also exploits the novel inhibitory action of Jaceidin, Centaureidin, Artecanin, Secotanaparthenolide, Artematin, Schizolaenone B, Isopomiferin, 6, 8-Diprenyleriodictyol, and Anthraxin against dengue virus. It is concluded that the screened 18 phytochemicals have strong inhibition potential against Dengue Virus 4.
\end{abstract}

Keywords: DENV4-NS1, Phytochemicals, Molecular Docking, Molecular Dynamics Simulations, Druglikeness

\section{INTRODUCTION}

Dengue Virus which is known to cause dengue fever belongs to the class flaviviral and genus flavivirus has four serotypes i.e. Dengue Virus 1 (DENV-1) to 4

*Correspondence: N. Rasool, Center for Professional Studies, Lahore, Pakistan.E-mail: noumanrasool@gmail.com
(DENV-4) (Searo, 2011). DENV-4 is quite prevalent in tropical and subtropical areas of the world, commonly Brazil as it is observed to spread rapidly throughout the several Brazilian states since 2010. It is strongly associated with serious cases of Dengue Shock Syndrome (DSS) and Dengue hemorrhagic fever (DHF) (Temporão et al., 2011). 
Dengue virus is comprised of a single strand RNA which encodes ten proteins including three structural and seven nonstructural proteins. The structural proteins are membrane protein $(\mathrm{M})$, capsid protein $(\mathrm{C})$, and envelope protein $(\mathrm{E})$. The remaining seven proteins are nonstructural proteins named as Non-structural protein 1 (NS1), Non-structural protein 2A (NS2A), Nonstructural protein 2B (NS2B), Non-structural protein 3 (NS3), Non-structural protein 4A (NS4A), Nonstructural protein 4B (NS4B) and Non-structural protein 5 (NS5) (Lindenbach and Rice, 2001). Nonstructural proteins are hydrophobic in nature and play a pivotal role in virus proliferation. The nonstructural proteins are only expressed in infected host cells. NS1 is considered to be the foundation of viral replication (Whitehead et al., 2007).

NS1 protein plays an important role in various stages of the life cycle of dengue virus 8-9. NS1 is secreted by infected mammalian cells and is released into the blood which leads towards disease. NS1 protein transports to the cell surface where it is further released into extracellular milieu as a hexameric form. The proper processing of NS1 requires sequence in the C-terminus of the envelope glycoprotein. It is synthesized and moved to the endoplasmic reticulum where it is modified into homodimer with partial hydrophobicity (Avirutnan et al., 2010). Non-Structural Protein 1 of Dengue Virus 4 (DENV4-NS1) is known to be involved in the replication and maturation of viron in the host cells. It is comprised of 352 amino acids, having 46 to $50 \mathrm{kDa}$ glycoprotein present in the cell membrane and is secreted in the blood to infect the cell (Scaturro et al., 2015).

Discovery of drugs against viruses is always an attractive area of research. It is considered that to prevent viral infection, its replication would have to be ceased at early stages of reproduction, growth, and development. Plants are an important natural source for the discovery of drugs against viruses, comprising of different groups of phytochemicals (secondary metabolites). Some major groups are alkaloids, flavonoids, monoterpenes, and sesquiterpenes. Different studies have been conducted to analyze the medicinal potentials of these phytochemicals against various diseases (Mirza et al., 2016).

The in silico characterization of DENV4-NS1 and its interaction with the phytochemicals from Tanacetum parthenium and Silybum marianum is targeted in this study. Tanacetum parthenium is a fever-reducing plant which belongs to Asteraceae found in gardens and along roadsides. It has been proved biologically active compound, used for the treatment of arthritis, asthma, constipation, fever, headache and inflammatory conditions (Chavez, Chavez, 1999). The widely studied chemical constituents in Tanacetum parthenium are sesquiterpene lactones, and flavonoids (Pareek et al., 2011). Silybum marianum, commonly known as milk thistle or blessed thistle, is also a member of Asteraceae and is locally inhabited in plant of Mediterranean regions, North Africa and Australia. The phytochemicals of Silybum marianum has importance due to its medicinal point of view, especially Betaine, Isosilibinin, Silibinin, Silidianin, Silychristin, and Silymarin (Hussain et al., 2010; Qaddir et al., 2017). The most important chemical Silymarin which is the further combination of seven compounds (Polyak et al., 2013). The current study focuses on the inhibitory action of phytochemicals from these two plants against dengue virus. The drug-likeness properties of these phytochemicals were also determined in this study for their efficient use in the control of the spread of disease caused by Dengue virus 4 .

\section{MATERIAL AND METHODS}

The methodology was comprised of several techniques and phases. An overview is being provided in the flowchart (Figure 1).

Tanacetum parthenium and Silybum marianum are medicinal plants locally produced in Pakistan. Phytochemicals of these plants are known to have an inhibitory effect against many viral diseases (Pareek et al., 2011; Polyak et al., 2013). The proposed study emphasized on the antiviral behaviour of these two plants against Non-Structural Protein 1 of Dengue Virus 4. About 50 phytochemicals (secondary metabolites) were selected from Tanacetum parthenium and 79 were selected from Silybum marianum to analyze their antiviral activity against DENV-4. Among these 129 phytochemicals, there were 91 flavonoids ( 79 from Silybum marianum and 12 from Tanacetum parthenium) 10 sesquiterpene from Tanacetum parthenium, and 28 monoterpenes which were also from Tanacetum parthenium. 


\section{Homology Modelling of DENV4-NS1}

\section{Binding site prediction}

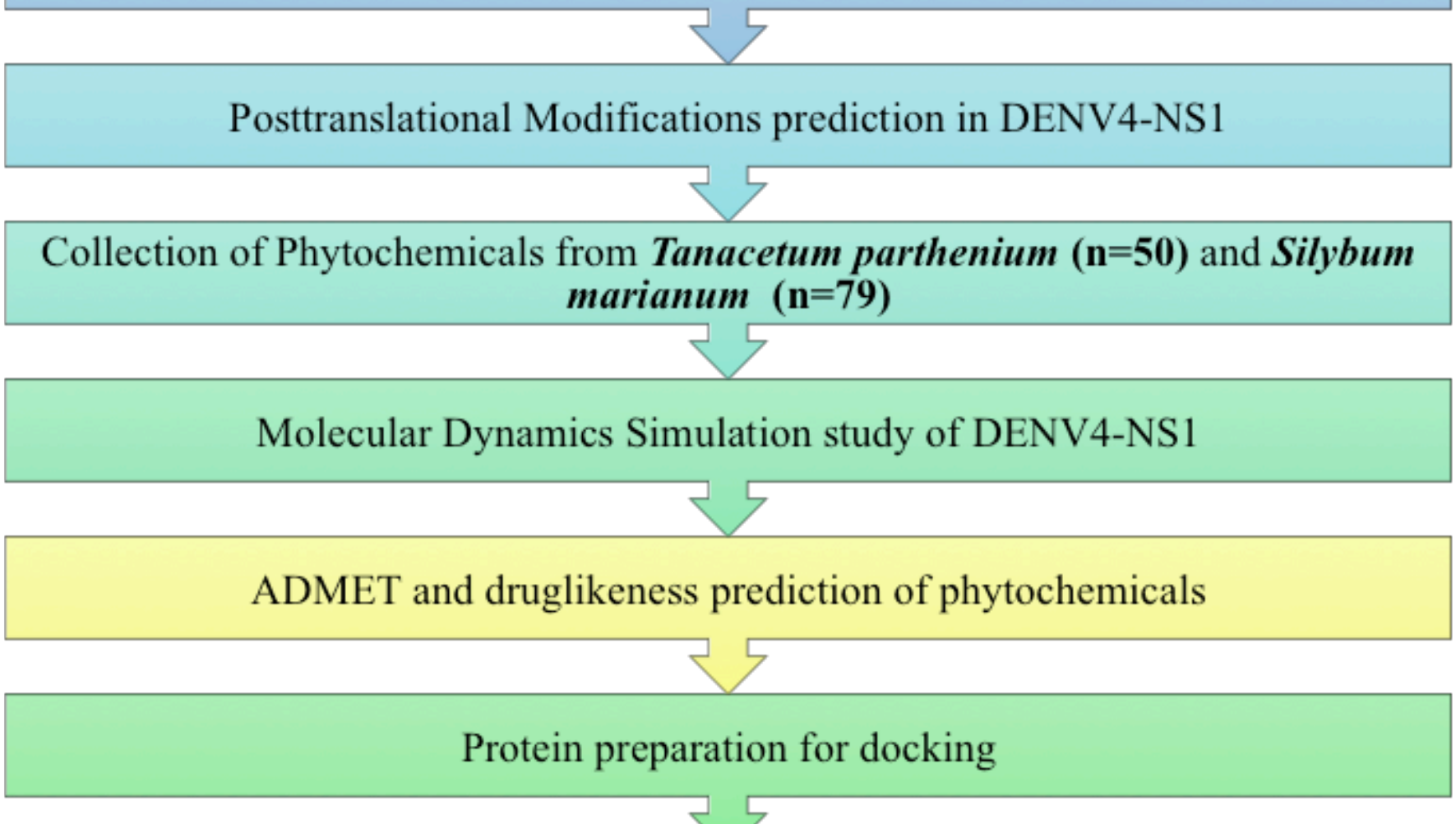

Ligands preparation( $\mathrm{n}=29$ from Silybum marianum and $\mathrm{n}=25$ from Tanacetum parthenium)

Molecular Docking

\begin{tabular}{|c|}
\hline Docking Score Evalaution \\
\hline Screening on basis of high binding affinity ( $\mathrm{n}=10$ from Silybum marianum and \\
$\mathrm{n}=8$ from Tanacetum parthenium)
\end{tabular}

FIGURE 1 - Flowchart of the methodology. 


\section{Collection of Phytochemicals}

\section{Homology modelling and binding site prediction}

The homology modelling of DENV4-NS1 was performed due to the unavailability of its tertiary structure in Protein Data Bank. With the help of Basic Local Alignment Search Tool (BLAST), similar homologous structures were found and top 4 structures with the highest similarity (Protein Databank Identifiers: 4O6B, 5IY3, 4OIG and 4OII) were selected as the template for the homology modelling (Johnson et al., 2008). Homology modelling was performed using Modeller 9.17. Python language based scripts were used for the profile building, comparison, twodimensional alignment, and modelling. Homology modelling generated 5 models and these models were evaluated on the basis of Discrete Optimized Protein Energy (DOPE) score. The model with the lowest DOPE was selected for further studies as per. The binding sites were predicted using MetaPocket Server (Huang, 2009).

\section{Posttranslational Modifications}

PTM including phosphorylation, glycosylation, ubiquitination, methylation, acetylation, and palmitoylation were performed on predicted model using NetPhos, BioCUCKOO server by the CUCKOO workgroup and Yin O Yang server (Gupta, Brunak, 2001; Blom et al., 2004).

\section{Molecular Dynamics Simulation}

Thermodynamics and structure dynamics of DENV4-NS1 were studied with the help of Groningen Machine for chemical simulation (GROMACS) $\mathrm{v}$ 5.0 (Abraham et al., 2015). Primarily, the optimized potential for liquid simulation force field was applied on all atoms (OPLS-AA). Neutralization of solvent was done by the addition of counter ions $\mathrm{Na}+$ and $\mathrm{Cl}-$ using Verlet cut-off scheme. The whole system was subjected to energy minimization (EM) by the use of the steepest descent algorithm, having 50000 steps. Equilibrations of the whole setup were performed involving the constant Number, Volume and Temperature (NVT) and Constant Number, Pressure and Temperature (NPT). During the whole process, pressure and temperature remained constant i.e. 1atm and $300 \mathrm{~K}$ respectively. The time duration for both equilibrations was $100 \mathrm{ps}$, while the Particle Mesh Ewald force field was used with cubic interpolation operation. Linear Constraint Solver (LINCS) was used for the modification of hydrogen bonds. Production molecular dynamics (MD) simulation was performed for $1 \mathrm{~ns}$ and the results of MD simulation were analyzed by the aid of RMSD and gyration in the backbone of the enzyme. Visual molecular dynamics (VMD) was used to view the molecular dynamics simulation results (Humphrey et al., 1996).

\section{ADMET and Drug-likeness Prediction}

Absorption, Distribution, Metabolism, Excretion and Toxicity of the phytochemicals from Silybum marianum and Tanacetum parthenium was calculated using SwissADME server and PreADMET server (Lee et al., 2003; Daina et al., 2017). The program also helped in predicting the pharmacokinetics, druglikeness and medicinal chemistry friendliness of all the phytochemicals. The prediction was made using the molecular structure files of all the molecules. Physically significant descriptors and pharmaceutically relevant properties associated with the ligand molecules were calculated. Phytochemicals were being assessed for the properties such as molecular weight being $<500$ Daltons with $<5$ hydrogen bond donors, $<$ 10 hydrogen bond acceptors and QPlogPo/w $<5$. The Gastrointestinal Absorption and Brain Penetration was predicted and represented using Boiled-Egg model (Daina, Zoete, 2016).

\section{Molecular Docking}

The chemical structures of phytochemicals were retrieved from PubChem compound database. Molecular Docking of phytochemicals against DENV4-NS1 protein was performed using AutoDock Tools and AutoDock Vina (Morris et al., 2009; Trott and Olson, 2010).

Receptor preparation for docking was done using Autodock Tools by adding hydrogen bonds and designing of a grid box. Ligands were also prepared with the same module, including torsion adjustments and modifications. Ligands were docked with the predicted model of DENV4-NS1 using AutoDock Vina and were evaluated on the basis of binding affinity. 


\section{RESULTS AND DISCUSSION}

\section{Structure of DENV4-NS1 and binding sites}

Based upon the primary structure of the DENV4NS1, it has shown maximum similarity (73\%) with DENV2- NS1. Among the five generated models by Modeller 9.17, the model with the lowest DOPE energy i.e. -29910.83 was selected for further studies (Figure 2). A Ramachandran plot was generated for the predicted model using RAMPAGE tool (Lovell et al., 2002). As per the analysis of possible conformations of $\phi$ and $\psi$ angles for individual amino acid residues in DENV4-
NS1, it was observed that $89.1 \%$ residues were in the favoured region and $10.0 \%$ residues were in the allowed region while only $0.9 \%$ residues were in outlier region (Figure 3). The predicted model of DENV4NS1 comprised of $4 \alpha$-helices and $12 \beta$-sheets while $2 \alpha$-helices and $17 \beta$-sheets are found in DENV2-NS1 (Akey et al., 2014). The superimposition of both tertiary structures illustrated that both structures have Template Match Score (TM-Score) and RMSD of 0.53 and 2.2 respectively. The binding sites in both protein models are highly conserved i.e. comprising of Val5, Lys14, Phe20, Ala187 and Lys189 (Figure 2).

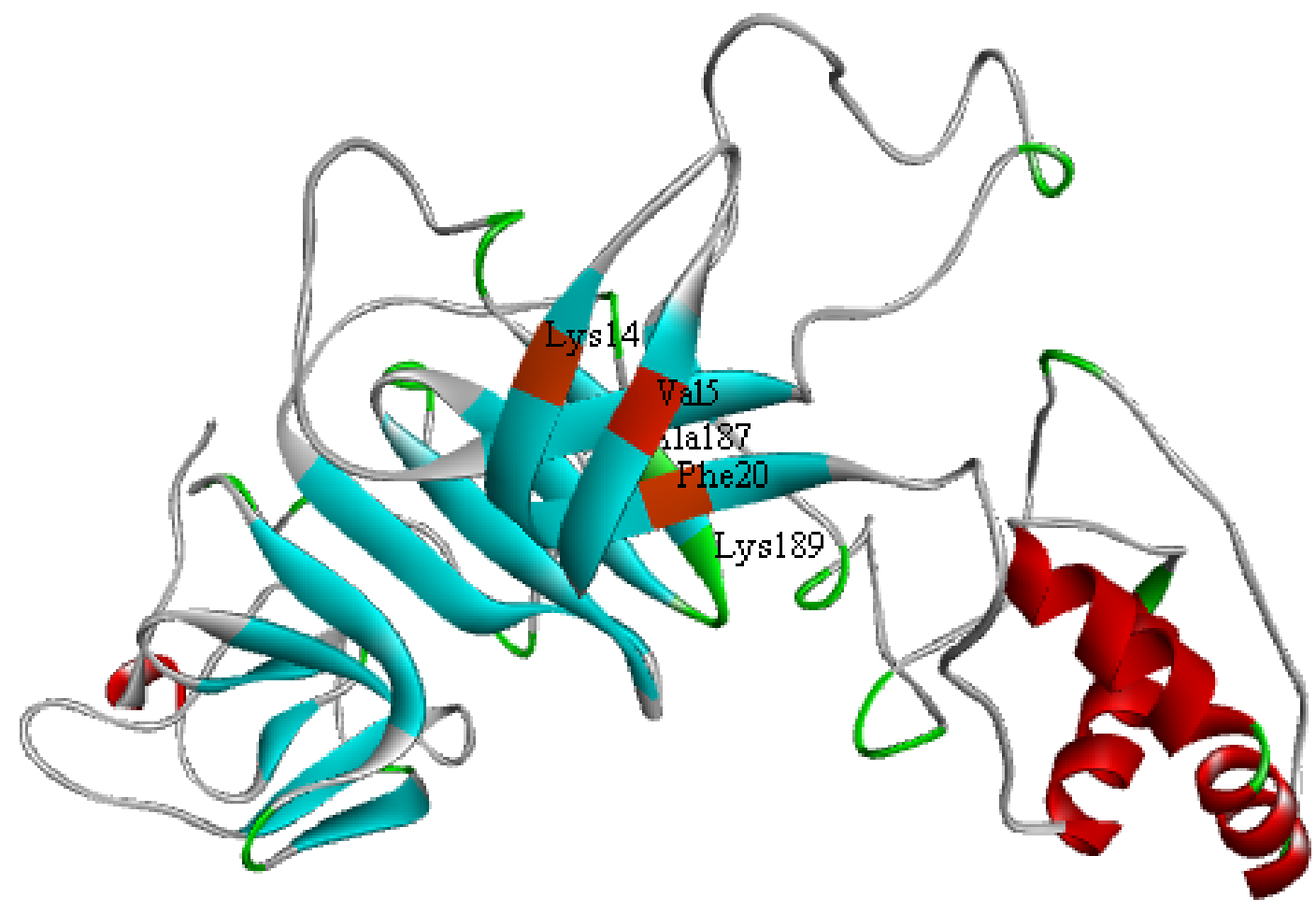

FIGURE 2 - Tertiary structure of DENV4-NS1 with predicted binding sites. 


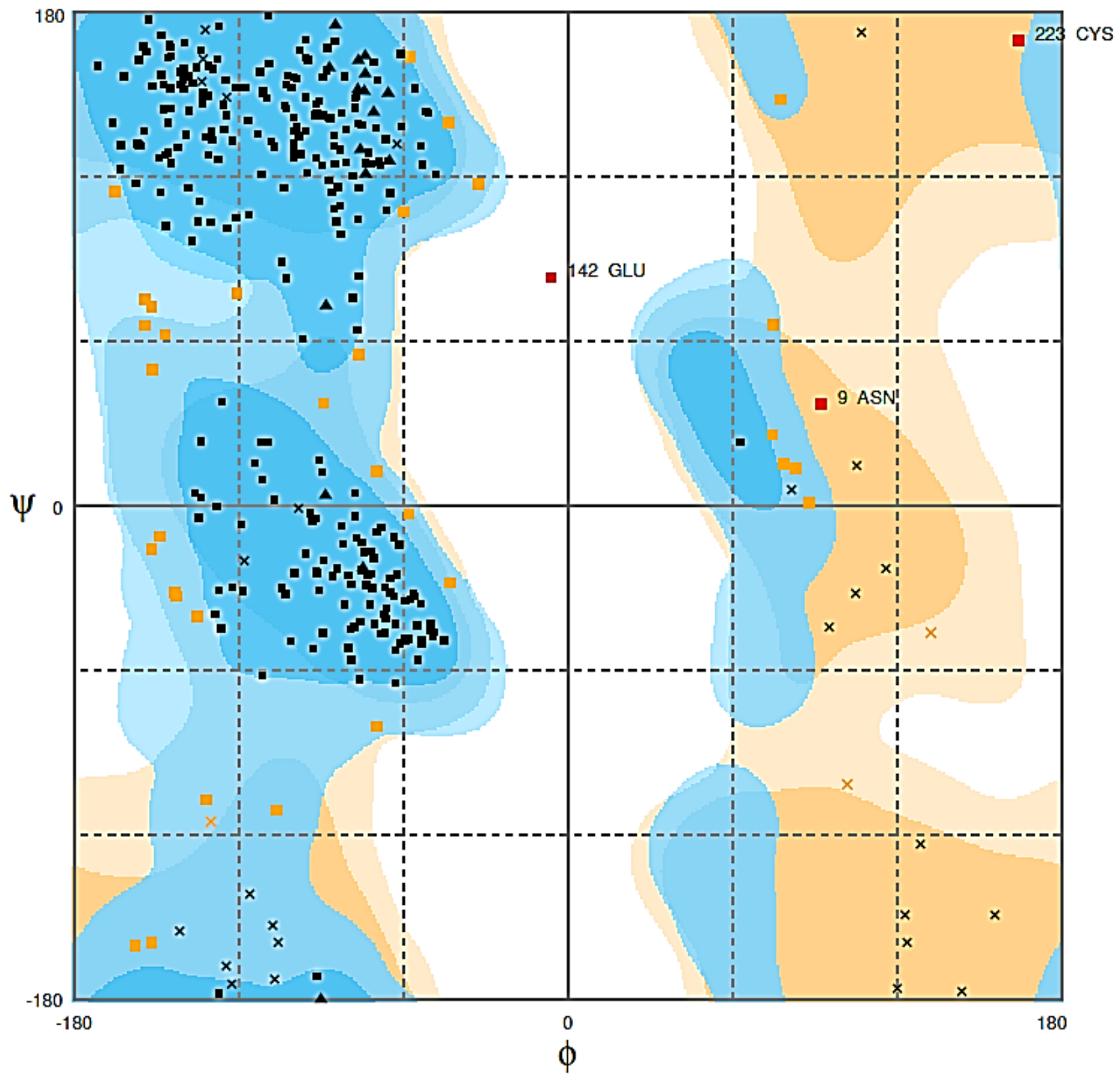

FIGURE 3 - Ramachandran plot of predicted DENV4-NS1.

\section{Posttranslational Modifications}

A total of 98 posttranslational modifications were predicted in the DENV4-NS1 model including 62 Phosphorylations, 11 Ubiquitinations, 11 Sumoylation, 7 glycosylation and 3 Palmitoylations. $O$-(beta)GlcNAc sites were also observed on 3 different sites. Ubiquitination can occur on Lys14 and Lys189, which are binding pocket residues if exposed to the exterior environment. Small ubiquitin-like modifier (SUMO) plays major roles in a reversible posttranslational modification process (SUMOylation) which actually monitor a wide range of cellular processes for numerous viruses during infection. The SUMOylation pathway is a key regulator of the DENV life cycle. It is also known to be involved in the regulation of replication in dengue virus (Su et al., 2016).

\section{Molecular Dynamics and Simulation}

Thermodynamics properties of the predicted model including temperature and total energy values are used 
to analyze the quality of the 3D structure of the protein. The structure of DENV4-NS1 obtained after dynamics simulations were compared with the crude predicted model without the simulation studies and were evaluated through TM-Score by superimposing both structures. The TM-Score value was observed to be 0.82 at $300 \mathrm{~K}$ while RMSD was 1.8. The compactness of structure was analyzed by unsteady gyration $(\mathrm{Rg})$ radius which showed that protein is not folded under the stable configurations (Figure 4).

The RMSD graph illustrated the instability of DENV4-NS1 structure under the high temperature, representing the mesophilic nature of protein as instability of the structure increased with increasing temperature (Figure 5).

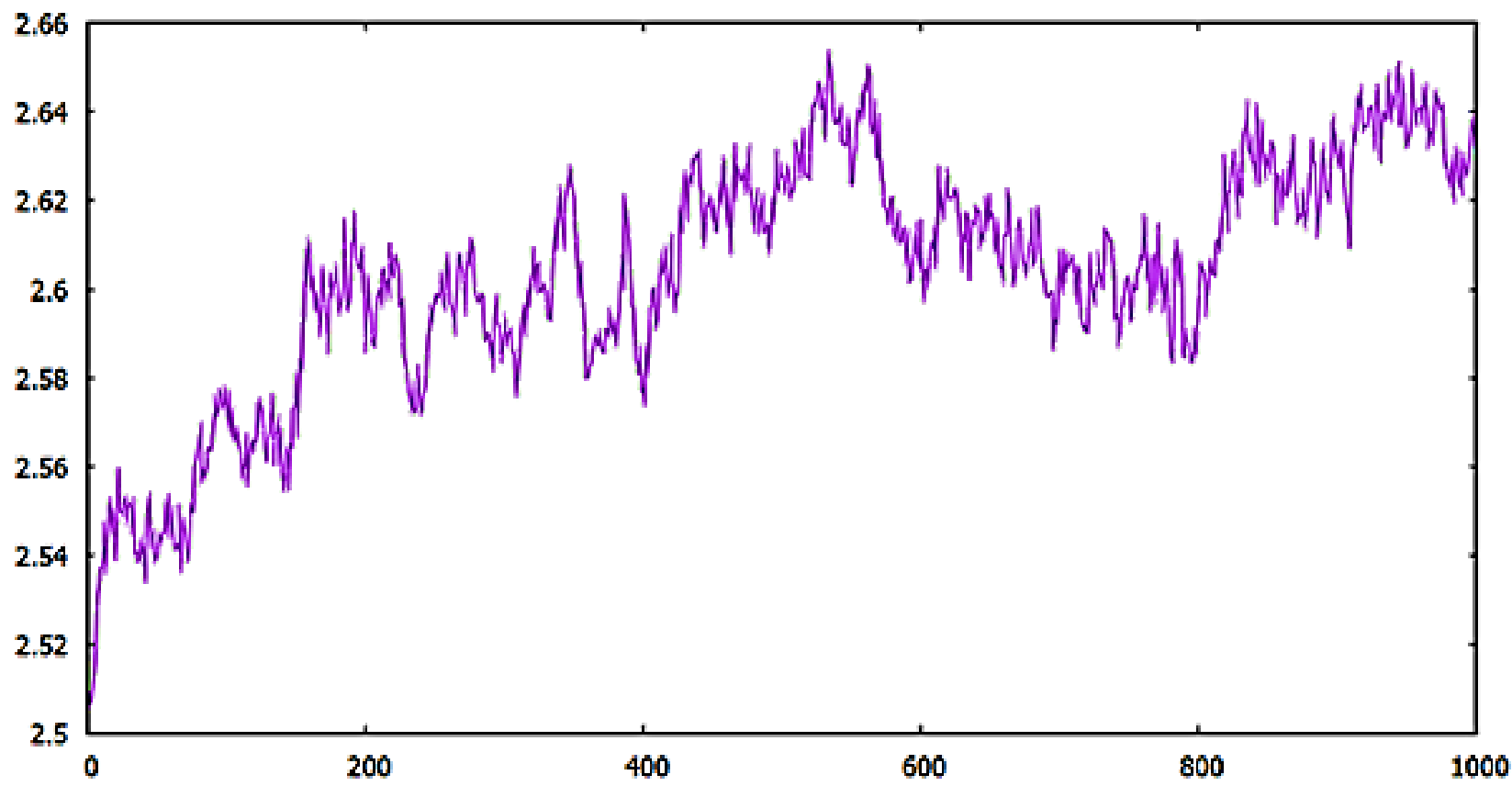

FIGURE 4 - Gyration plot of DENV4-NS1 at 300K.

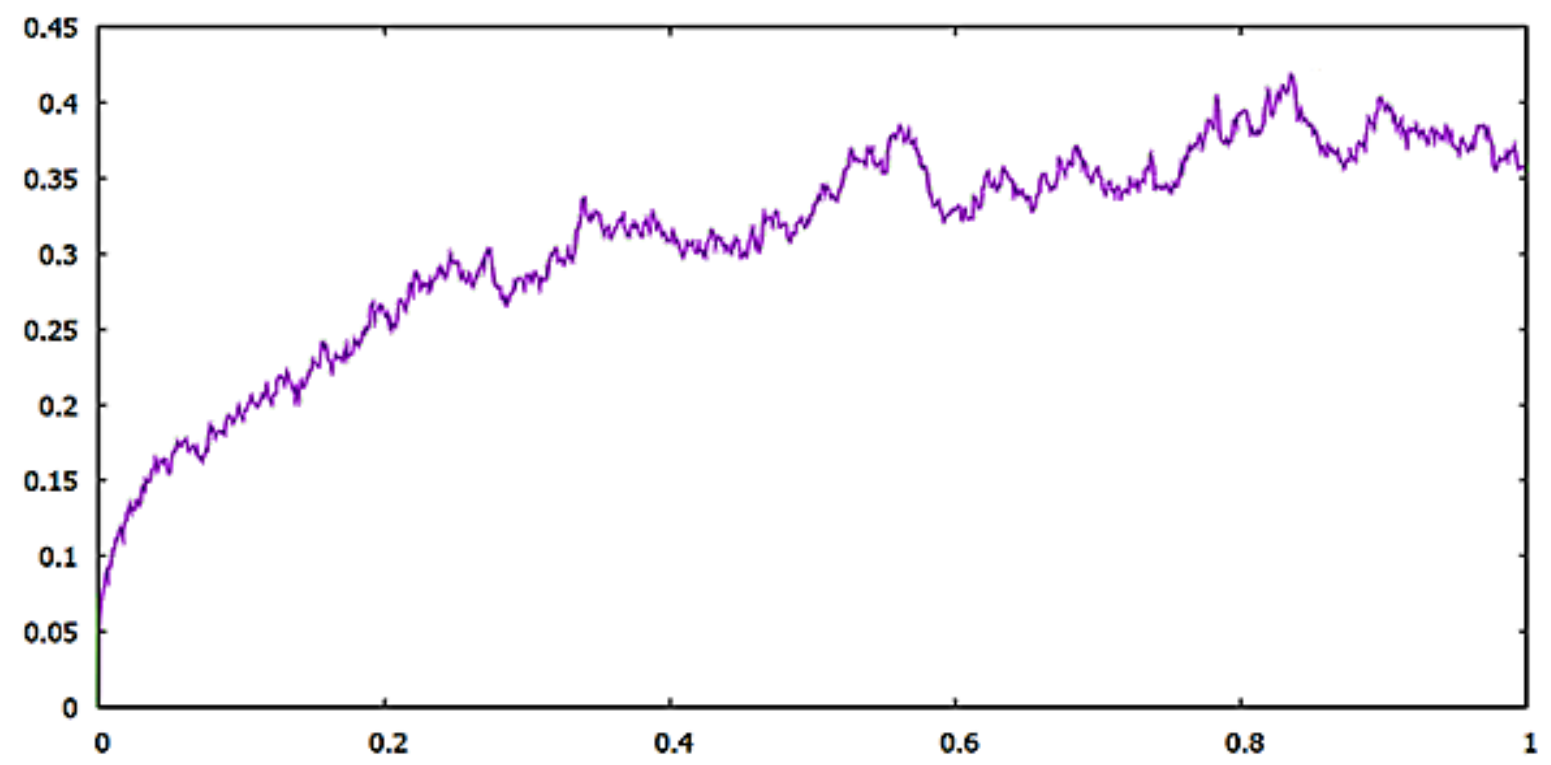

FIGURE 5 - RMSD plot of DENV4-NS1 at 300K. 


\section{Drug suitability and their virtual screening}

ADMET and drug-likeness prediction were performed for 129 phytochemicals (secondary metabolites). The results of the ADMET and druglikeness helped in evaluating the phytochemicals for their use as potential drugs in the dengue fever. A total of 54 phytochemicals i.e. 29 from Silybum marianum and 25 from Tanacetum parthenium were predicted be suitable on the basis of Lipinski's rule of 5.

The phytochemicals from Silybum marianum are flavonoids and have low solubility in water as compared to the few phytochemicals from Tanacetum parthenium, having sesquiterpene nature. Moreover, it was observed that gastrointestinal absorption was high in all the phytochemicals from both plants. Therefore these can be used effectively as drugs against human dengue virus 4 .

The most suitable drugs, which were also docked with high binding affinities, were further filtered on the basis of the Blood-Brain Barrier (BBB) penetration behaviour. The $\mathrm{BBB}$ is a mechanism which does not usually allow the drugs reaching the brain and central nervous system and it is preferred that a drug should not usually approach the central nervous system (Tran, 2011). Non-penetrating drugs were considered as final candidates.

\section{Docking with phytochemicals}

DENV4-NS1 was subjected to docking with 54 phytochemicals which showed effective ADMET properties. Among these 54 phytochemicals, 18 (10 from Silybum marianum and 8 from Tanacetum parthenium) docked successfully at the binding site of DENV4-NS1 with high binding affinities. These are shown occupying binding site of DENV4-NS1 protein and their ADMET properties are also mentioned (Table I-II). High binding affinities show that these chemicals are tightly bound to the active site of DENV4-NS1 (Table III). Inhibition of viral proteins by phytochemicals would result in reduced viral replication, hence control the spread of dengue fever (N Powers and N Setzer, 2016).

TABLE I - Phytochemicals from Tanacetum parthenium and Silybum marianum

Centaureidin

$$
\mathrm{C}_{18} \mathrm{H}_{16} \mathrm{O}_{8}
$$<smiles>COc1ccc(-c2oc3cc(O)c(OC)c(O)c3c(=O)c2OC)cc1O</smiles> 
TABLE I - Phytochemicals from Tanacetum parthenium and Silybum marianum

Parthenolide $\mathrm{C}_{15} \mathrm{H}_{20} \mathrm{O}_{3}$

Jaceidin $\mathrm{C}_{18} \mathrm{H}_{16} \mathrm{O}_{8}$

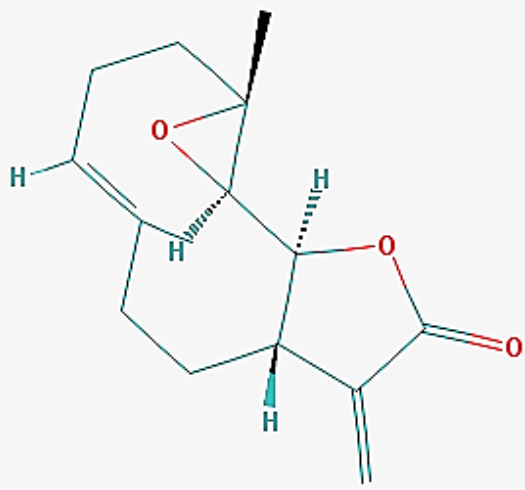

Santin

$\mathrm{C}_{18} \mathrm{H}_{16} \mathrm{O}_{7}$<smiles>COc1ccc(-c2oc3cc(O)c(OC)c(O)c3c(=O)c2OC)cc1</smiles> 
Secotanaparthenolide B

Quercetin

Artecanin
$\mathrm{C}_{15} \mathrm{H}_{18} \mathrm{O}_{5}$

$\mathrm{C}_{15} \mathrm{H}_{10} \mathrm{O}_{7}$<smiles>O=c1c(O)c(-c2ccc(O)c(O)c2)oc2cc(O)cc(O)c12</smiles>

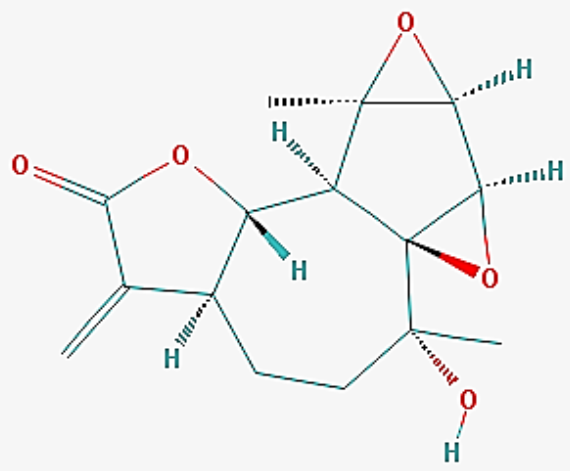


TABLE I - Phytochemicals from Tanacetum parthenium and Silybum marianum

Artematin

$\mathrm{C}_{20} \mathrm{H}_{20} \mathrm{O}_{8}$<smiles>COc1ccc(-c2oc3cc(OC)c(OC)c(O)c3c(=O)c2OC)cc1OC</smiles><smiles>COc1cc(C2Oc3cc(-c4oc5cc(O)cc(O)c5c(=O)c4O)ccc3OC2CO)ccc1O</smiles>

Silybin

$\mathrm{C}_{25} \mathrm{H}_{22} \mathrm{O}_{10}$<smiles>COc1cc([C@H]2Oc3cc([C@H]4Oc5cc(O)cc(O)c5C(=O)[C@@H]4O)ccc3O[C@@H]2CO)ccc1O</smiles> 
Silymarin

Flavobion

6,8-Diprenyleriodictyol
$\mathrm{C}_{25} \mathrm{H}_{22} \mathrm{O}_{10}$<smiles>COc1cc([C@H]2Oc3cc(C4Oc5cc(O)cc(O)c5C(=O)[C@@H]4O)ccc3O[C@@H]2CO)ccc1O</smiles>

$\mathrm{C}_{25} \mathrm{H}_{22} \mathrm{O}_{10}$<smiles>COc1cc([C@H]2Oc3cc(C4Oc5cc(O)cc(O)c5C(=O)[C@H]4O)ccc3OC2CO)ccc1O</smiles><smiles>CC(C)=CCc1c(O)c(CC=C(C)C)c2c(c1O)C(=O)C[C@@H](c1ccc(O)c(O)c1)O2</smiles> 
TABLE I - Phytochemicals from Tanacetum parthenium and Silybum marianum

Anthraxin

$\mathrm{C}_{21} \mathrm{H}_{16} \mathrm{O}_{8}$<smiles>CC(O)Cc1cc(=O)c2c(cc(O)c3c(=O)cc(-c4ccc(O)c(O)c4)oc32)o1</smiles>

Silydianin A

$\mathrm{C}_{25} \mathrm{H}_{22} \mathrm{O}_{10}$

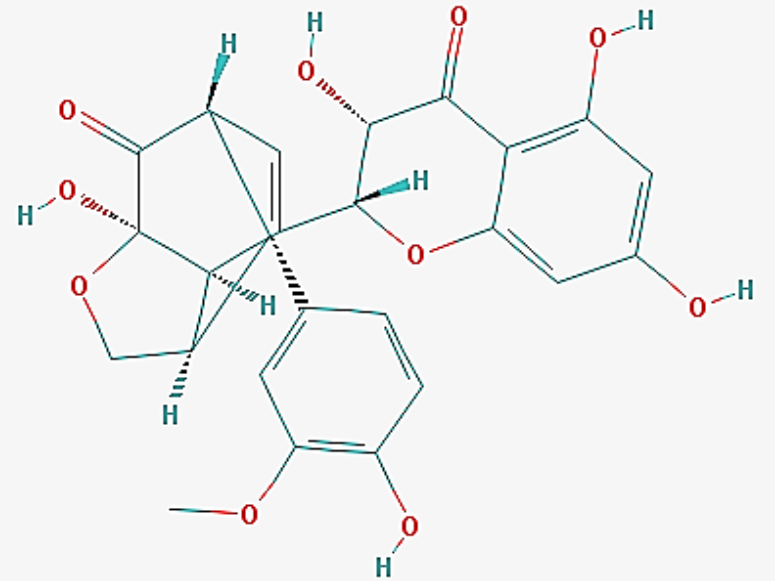

Schizolaenone B

$\mathrm{C}_{30} \mathrm{H}_{36} \mathrm{O}_{6}$

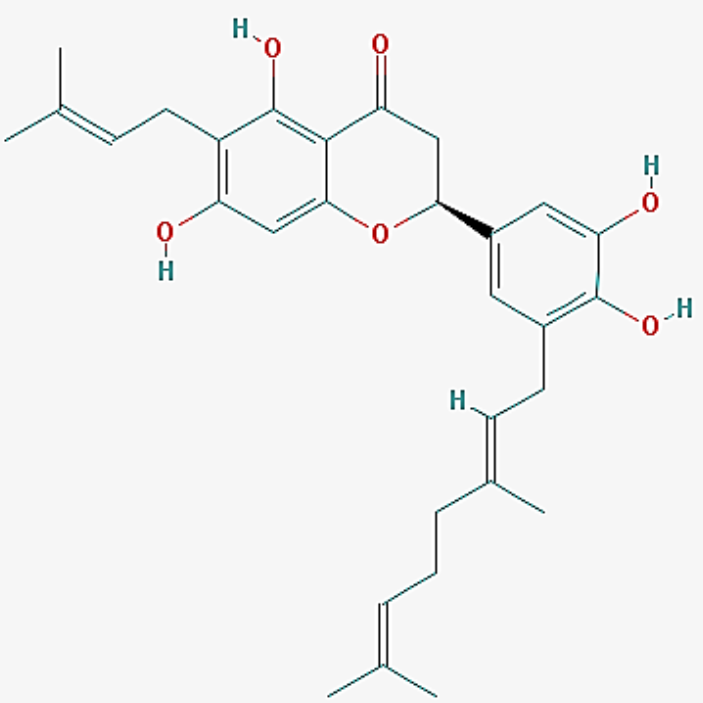


TABLE I - Phytochemicals from Tanacetum parthenium and Silybum marianum

Silydianin B

$\mathrm{C}_{25} \mathrm{H}_{22} \mathrm{O}_{10}$

Isopomiferin

$\mathrm{C}_{25} \mathrm{H}_{24} \mathrm{O}_{6}$
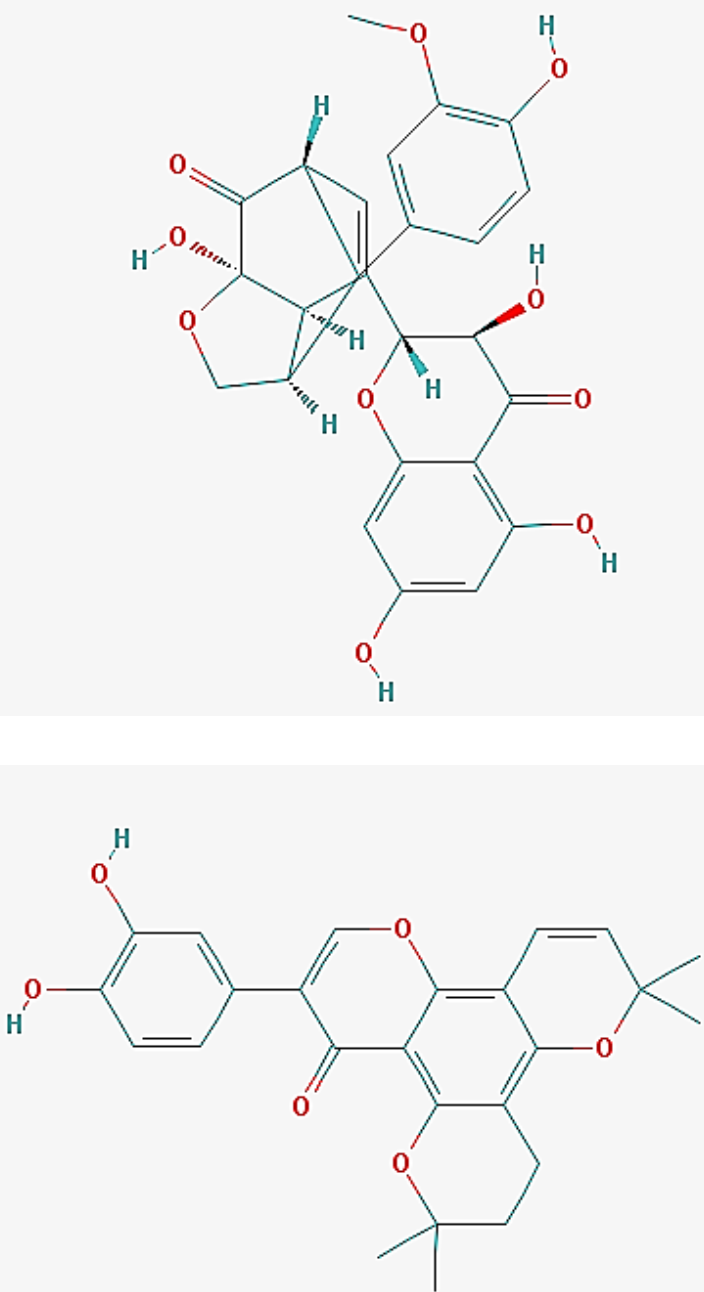
TABLE II - Results of Drug likeness from both plants

\begin{tabular}{|c|c|c|c|c|c|c|c|}
\hline Molecule & $\begin{array}{l}\text { ESOL } \\
\log S\end{array}$ & ESOL Class & $\begin{array}{c}\text { GI } \\
\text { absorption }\end{array}$ & $\begin{array}{c}\text { BBB } \\
\text { permeant }\end{array}$ & $\begin{array}{c}\text { Lipinski } \\
\text { violations }\end{array}$ & Toxicity & Carcinogenecity \\
\hline \multicolumn{8}{|c|}{ Tanacetum parthenium } \\
\hline Artecanin & -3.1 & Soluble & High & No & 0 & Non Toxic & Non carcinogenic \\
\hline Artementin & -4.15 & $\begin{array}{c}\text { Moderately } \\
\text { soluble }\end{array}$ & High & No & 0 & Non Toxic & Non carcinogenic \\
\hline Centaureidin & -5.5 & $\begin{array}{c}\text { Moderately } \\
\text { soluble }\end{array}$ & High & No & 0 & Non Toxic & Non carcinogenic \\
\hline Parthenolide & -4.44 & $\begin{array}{c}\text { Moderately } \\
\text { soluble }\end{array}$ & High & No & 1 & Non Toxic & Non carcinogenic \\
\hline Jaceidin & -2.29 & Soluble & High & No & 0 & Non Toxic & Non carcinogenic \\
\hline Quricetin & -4 & Soluble & High & No & 0 & Non Toxic & Non carcinogenic \\
\hline Santin & -4.89 & $\begin{array}{c}\text { Moderately } \\
\text { soluble }\end{array}$ & High & No & 1 & Non Toxic & Non carcinogenic \\
\hline Secotanaparthenolide B & -1.92 & Soluble & High & No & 0 & Non Toxic & Non carcinogenic \\
\hline
\end{tabular}

Silybum marianum

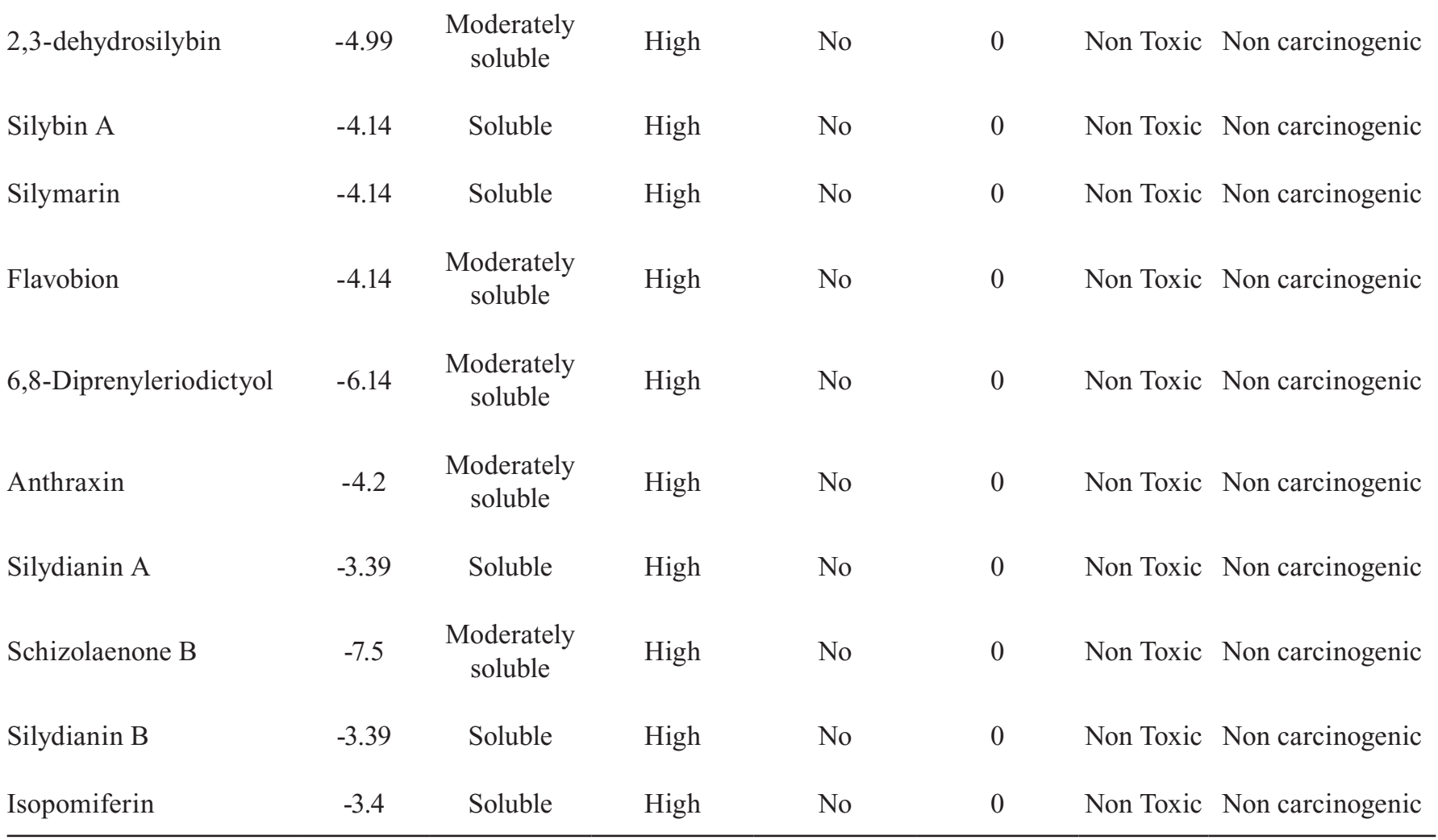


TABLE III - Docking of phytochemicals from Tanacetum parthenium and Silybum marianum with DENV4-NS1

\section{Tanacetum parthenium}

Centaureidin

Parthenolide

Jaceidin

Santin

Secotanaparthenolide B

Quercetin

Artematin
Artecanin

$$
\mathrm{Asn}_{9}, \mathrm{Lys}_{14}, \mathrm{Phe}_{20}, \mathrm{Ala}_{187}, \mathrm{Lys}_{189}, \mathrm{Lys}_{192}
$$$$
\mathrm{Val}_{5}, \operatorname{Asn}_{9,} \mathrm{Lys}_{189}, \mathrm{Lys}_{192}
$$$$
\mathrm{Ser}_{7}, \operatorname{Trp}_{8}, \mathrm{Asn}_{9} \mathrm{Gly}_{18} \mathrm{Phe}_{20} \text {, }
$$$$
\mathrm{Val}_{21}, \mathrm{Ala}_{187}, \mathrm{Lys}_{189}, \mathrm{Lys}_{192}
$$$$
\mathrm{Val}_{5}, \operatorname{Trp}_{8}, \mathrm{Asn}_{9,}, \text { Gly }_{18,} \text { Ile }_{19}, \text { Lys }_{189}
$$$$
\mathrm{Val}_{5}, \operatorname{Trp}_{8}, \mathrm{Asn}_{9}, \text { Lys }_{14}, \mathrm{Ile}_{19}, \text { Lys }_{189}
$$$$
\mathrm{Val}_{5}, \operatorname{Trp}_{8}, \mathrm{Asn}_{9}, \text { Lys }_{189}, \text { Lys }_{192}
$$$$
\operatorname{Ser}_{7,} \operatorname{Val}_{21}, \mathrm{Ala}_{187}, \mathrm{Lys}_{189}, \mathrm{Lys}_{192}
$$$$
\mathrm{Val}_{5,}, \operatorname{Trp}_{8}, \mathrm{Lys}_{189}
$$

\section{Silybum marianum}

\section{2,3-Dehydrosilybin}

Silybin A

Silymarin

Flavobion

6,8-Diprenyleriodictyol

Anthraxin

Silydianin A

Schizolaenone B

Silydianin A

Isopomiferin

$$
\begin{gathered}
\mathrm{Asn}_{9}, \mathrm{Ser}_{17}, \mathrm{Ile}_{19} \mathrm{Phe}_{20}, \\
\mathrm{Ala}_{187}, \mathrm{Lys}_{189}, \mathrm{Lys}_{192}
\end{gathered}
$$

$$
\mathrm{Met}_{2}, \mathrm{Val}_{5}, \mathrm{Asn}_{9}, \mathrm{Phe}_{20}, \mathrm{Val}_{21}, \mathrm{Lys}_{192}
$$

$$
\mathrm{Ile}_{19}, \mathrm{Phe}_{20}, \mathrm{Ala}_{187}, \mathrm{Lys}_{189}, \text { Lys }_{192}
$$

$\mathrm{Ser}_{7}, \mathrm{Trp}_{8}, \mathrm{Asn}_{9}, \mathrm{Lys}_{14}, \mathrm{Ile}_{19}, \mathrm{Phe}_{20}$,

$$
\mathrm{Val}_{21}, \mathrm{Ala}_{187}, \mathrm{Lys}_{189}, \mathrm{Lys}_{192}
$$

$-7.8$

$-8.6$

$-7.7$

$-8.0$

$$
\operatorname{Trp}_{8}, \mathrm{Asn}_{9}, \mathrm{Lys}_{14}, \mathrm{Lys}_{189}, \mathrm{Lys}_{192}, \operatorname{Trp}_{201}
$$

$\mathrm{Val}_{5}, \mathrm{Ser}_{7}, \mathrm{Lys}_{14}, \mathrm{Gly}_{18}, \mathrm{Phe}_{20}, \mathrm{Val}_{21}, \mathrm{Lys}_{189}$

$\mathrm{Val}_{5}, \operatorname{Trp}_{8}, \mathrm{Asn}_{9}, \mathrm{Ala}_{187}, \mathrm{Lys}_{189}$,

$\mathrm{Val}_{5}, \operatorname{Trp}_{8}, \mathrm{Asn}_{9}, \mathrm{Ala}_{187}, \mathrm{Lys}_{189}$,

$\mathrm{Val}_{5}, \operatorname{Trp}_{8}, \mathrm{Asn}_{9}, \mathrm{Ala}_{187}, \mathrm{Lys}_{192}$

$-8.7$
0.413
20.117

$$
\begin{aligned}
& \text { Val }_{21}, \operatorname{Asp}_{23}, \mathrm{Ala}_{187}, \mathrm{Lys}_{189}, \\
& \mathrm{Lys}_{192}, \operatorname{Trp}_{201}, \mathrm{Glu}_{263}
\end{aligned}
$$




\section{Docking of Tanacetum parthenium}

phytochemicals against DENV4 - NS1

A total of 25 phytochemicals of T. parthenium were used for docking with DENV4 - NS1. The binding affinities of these phytochemicals ranged from -4.8 to $-8.7 \mathrm{~kJ} / \mathrm{mol}$. A threshold of $-6.0 \mathrm{kcal} / \mathrm{mol}$ was used for screening the compounds and out of the 25, 8 phytochemicals passed this threshold by making interactions with Val5, Ser7, Trp8, Asn9 Gly18, Phe20, Val21, Ala187, Lys189, and Lys192 residues of the binding pocket.

Parthenolide made interactions with Val5, Asn9, Lys189, Lys192 having binding affinity $-8.6 \mathrm{kcal} / \mathrm{mol}$ $(\mathrm{Ki}=0.489 \mu \mathrm{M})$. Quercetin having a binding affinity $-8.0 \mathrm{kcal} / \mathrm{mol}(\mathrm{Ki}=1.347 \mu \mathrm{M})$ inhibited DEN4-NS1 by making interactions with Val5, Trp8, Asn9, Lys189 and Lys192. Santin and Secotanaparthenolide B showed binding affinity $-7.4 \mathrm{kcal} / \mathrm{mol}(\mathrm{Ki}=3.713 \mu \mathrm{M})$ and made interactions with Val5, Trp8, Asn9, Gly18, Ile19 and Lys189 residues of the binding pocket. Artecanin also docked with a binding affinity $-7.4 \mathrm{kcal} / \mathrm{mol}(\mathrm{Ki}$ $=3.713 \mu \mathrm{M})$ and made interactions with Ser7, Val21, Ala187, Lys189 and Lys192. Jaceidin docked with a binding affinity $-7.0 \mathrm{kcal} / \mathrm{mol}(\mathrm{Ki}=7.299 \mu \mathrm{M})$ at binding pocket, making interactions with Ser7, Trp8, Asn9 Gly18, Phe20, Val21, Ala187, Lys189 and Lys192. Centaureidin and Artematin docked with a binding affinity $-6.4 \mathrm{kcal} / \mathrm{mol}(\mathrm{Ki}=20.117 \mu \mathrm{M})$ by making interactions with Asn9, Lys14, Phe20, Ala187, Lys189 and Lys192 residues of the binding pocket. The proposed study has highlighted novel inhibition potential of phytochemicals from Tanacetum parthenium against dengue virus which are Jaceidin, Centaureidin, Artecanin, Secotanaparthenolide, and Artematin. The application of these phytochemicals against dengue virus is not reported previously in any study.

Antiplasmodial and antiproliferative effects of Centaureidin and Jaceidin have been reported (Pareek et al., 2011). Both were also analyzed against chromosomal breakage in mitogen-induced human lymphocytes (Aljancix et al., 2010). The mitotic blocking activity by closely related flavonols i.e. Santin, Jaceidin and Centaureidin obtained from Tanacetum parthenium have also been reported (Long et al., 2003).

Sesquiterpene lactones like Parthenolide, 3-betahydroxyparthenolide, Secotanaparthenolide, canin and Artecanin present in the extract of Tanacetum parthenium have been reported to inhibit the secretion of granular contents from platelets and neutrophils (Marles et al., 1992). Artematin, which is a flavonoid, is known for the reduction of plasma and vascular ACE activity in vitro (de Souza et al., 2011). Antioxidant activity, hepatoprotective activity, antibacterial activity, lipoxygenase inhibition and antiproliferative activity have also been reported for Artematin (Csupor-Löffler et al., 2009; Choudhary et al., 2009; Michielin et al., 2009; Sridevi et al., 2012). Besides the novel antiviral agents, various phytochemicals with already reported antiviral activity have been docked successfully such as Costunulide, Parthenolide, and Quercetin. Costunolide, which is present in Tanacetum parthenium as well as in different medicinal plants such as Saussurea lappa and Laurus nobilis, has been analyzed against various types of cancer including Leukaemia, liver cancer, ovarian cancer, prostatic cancer and bladder cancer (Choi et al., 2009; Butturini et al., 2011; Liu et al., 2011; Kim et al., 2012).

Parthenolide, a sesquiterpene lactone, is an important phytochemical in Tanacetum parthenium which docked with high binding affinity against DENV4NS1 $(-8.6 \mathrm{kcal} / \mathrm{mol})$. It is reported against Epstein-Barr virus, migraines and rheumatoid arthritis for hundreds of years. Several studies have reported it performing inhibition of cell proliferation and DNA synthesis, and antitumor activity in various cancer cell lines (Kapadia et al., 2002; Pareek et al., 2011).

Quercetin is known to play an important role in the maintenance of physically and mentally human health as it reduces the risk of different infections due to its unique biological properties. Quercetin has been used for the treatment of cancer, oxidative damage and infections due to virus and bacteria (Markham, 1989). Quercetin has been observed to binding tightly with DENV4-NS1 having an excellent binding affinity $(-8.0 \mathrm{kcal} / \mathrm{mol})$. Previously, it has also been reported to show strong inhibition potential against another nonstructural protein namely NS2B/NS3 protease from DENV2 (Senthilvel et al., 2013).

\section{Docking of Silybum marianum phytochemicals with DENV4-NS1}

By analyzing ADMET properties of phytochemicals from Silybum marianum, 29 phytochemicals showed effective properties and these were docked against DENV4-NS1. A threshold of $-6.0 \mathrm{kcal} / \mathrm{mol}$ was used for screening the compounds and out of the 29, 10 
phytochemicals passed this threshold. Val5, Ser7, Trp8, Asn9, Gly18, Phe20, Val21, Ala187, Lys189, and Lys192 were involved in binding of these compounds.

Isopomiferin docked with highest binding affinity $-8.7 \mathrm{kcal} / \mathrm{mol}(\mathrm{Ki}=0.413 \mu \mathrm{M})$, inhibiting the protein by making interactions with Val21, Asp23, Ala187, Lys189, Lys192, Trp201, Glu263 residues of the binding pocket. Silydianin A and Silydianin B made interactions with Val5, Trp8, Asn9, Ala187 and Lys192 residues of the binding pocket. Silydianin A docked with binding affinity $-8.6 \mathrm{kcal} / \mathrm{mol}(\mathrm{Ki}=0.489 \mu \mathrm{M})$ while Silydianin B docked with binding affinity $-8.0 \mathrm{kcal} / \mathrm{mol}(\mathrm{Ki}=1.347 \mu \mathrm{M}) .2$, 3-dehydrosilybin made interactions with the binding pocket residues Asn9, Ser17, Ile19, Phe20, Ala187, Lys189 and Lys192, docking with binding affinity $-7.8 \mathrm{kcal} /$ mol $(\mathrm{Ki}=1.889 \mu \mathrm{M})$. Similarly, 6,8-Diprenyleriodictyol docked with binding affinity $-7.8 \mathrm{kcal} / \mathrm{mol}(\mathrm{Ki}=1.889$ $\mu \mathrm{M})$ by making interactions with Trp8, Asn9, Lys14, Lys189, Lys192 and Trp201. Silybin A and Flavobion docked with binding affinity $-7.7 \mathrm{kcal} / \mathrm{mol}(\mathrm{Ki}=2.237$ $\mu \mathrm{M})$. Silybin made interactions with Met2, Val5, Asn9, Phe20, Val21 and Lys192 while Flavobion interacted with Ser7, Trp8, Asn9, Lys14, Ile19, Phe20, Val21, Ala187, Lys189 and Lys192 residues of the binding pocket. Similarly, Anthraxin and Schizolaenone B docked with binding affinity $-7.7 \mathrm{kcal} / \mathrm{mol}(\mathrm{Ki}=2.237 \mu \mathrm{M})$. Anthraxin interacted with Val5, Ser7, Lys14, Gly18, Phe20, Val21 and Lys189 residues while Schizolaenone B made interactions with Val5, Trp8, Asn9, Ala187, Lys189 residues of the binding pocket. Silymarin made interactions with Ile19, Phe20, Ala187, Lys189 and Lys192 residues of binding pocket with binding affinity $-7.6 \mathrm{kcal} / \mathrm{mol}(\mathrm{Ki}=2.648$ $\mu \mathrm{M})$. The proposed study presents the novel inhibitory activities of phytochemicals from Silybum marianum i.e. Schizolaenone B, Isopomiferin, 6, 8-Diprenyleriodictyol, and Anthraxin against dengue virus.

Schizolaenone B has been analyzed against the A2780 human ovarian cancer cell line while Isopomiferin has been reported for having antioxidant properties (Murphy et al., 2005; Diopan et al., 2008).

Antiproliferativepropertiesof6,8-diprenyleriodictyol for leukaemia and solid cancer cells have been reported (Keute et al., 2011). Other activities such as antimicrobial activity and antioxidant activity have also been reported (Dufall et al., 2003Dzoyem et al., 2013). Anthraxin has been used for Immunological vaccination showing best results against various viral disease (Shlyakovm, 1994).

The phytochemicals of Silybum marianum showed the potent inhibitory effect against DENV4-NS1. Silymarin, a well-studied phytochemical of Silybum marianum was docked effectively against DENV4-NS1 and showed good binding affinity. Studies show that Silymarin has an inhibitory effect against acute and chronic viral hepatitis liver disease, hepatotoxicity and liver cancer (Agarwal et al., 2006; Wagoner et al., 2010; Freedman et al., 2011). Different studies analyzed that silymarin extracted from Silybum marianum inhibits HCV in both, in vitro and in vivo, by inhibiting viron entry, viral transcription and translation, and production of infectious virus (Anthony and Saleh, 2013). Silymarin shows anti-inflammatory, anti-fibrotic, and antioxidant activities. Silymarin has been observed to inhibit the post-entry steps of CHIKV infection significantly (Lani et al., 2015).

This study was based on computer-aided drug development against dengue 4 virus. Targeting the in silico approach to drug discovery, the molecular dynamics simulations help in the study of the motions of biological macromolecules such as proteins and nucleic acids. Atomistic computer simulations of therapeutic proteins/enzyme help in the discovery and development of drug through the identification of binding sites using various traditional methodologies of virtual screening, and prediction of binding energies of ligand/protein complex. Posttranslational modifications (PTM) of a protein are used for covalent modification of the protein by non-protein molecule. PTM is the process which is used as a post-process of biosynthesis when a genome is transformed into a proteome. The drugs are actually the inhibitors for a specific enzyme involved in an onset of the specific pathological condition. The docking of such inhibitors with the enzymes elucidate the mechanism of inhibition along with the specificity and efficiency of that inhibitor. Around $40 \%$ of drugs which are discovered through in silico molecular docking fail in clinical trials if the ADMET (absorption, distribution, metabolism, excretion and toxicity) properties are not analyzed in these approaches. These failures can lead to finding new drugs that can be costly. Accurate prediction of ADMET properties can help in overcoming these failures and can be inexpensive. The in silico approach for drug discovery helps in finding drugs for diseases instead of the experimental work by docking mechanism. Drug development methods, purposed in this study can be helpful for further studies in vitro and in vivo analyses against dengue viral diseases. In the proposed study, 18 phytochemicals from both plants were identified as potential inhibitors against dengue virus 4 . These novel inhibitors include Jaceidin, Centaureidin, Artecanin, 
Secotanaparthenolide and Artematin from Tanacetum parthenium while Schizolaenone B, Isopomiferin, 6, 8-Diprenyleriodictyol, and Anthraxin from Silybum marianum. It is concluded that the screened 18 compounds from both of the plants can be used as therapeutic agents against dengue fever, specifically from Dengue Virus 4.

Most of the phytochemicals have been reported to be used in humans for the treatment of various diseases. Such studies support our hypothesis that these chemicals are not only good curative agents against dengue virus but also are biologically safe for human use, so the development of these phytochemicals as potential drugs for dengue virus would be therapeutically and economically beneficial.

\section{REFERENCES}

Abraham MJ, Murtola T, Schulz R, Páll S, Smith JC, Hess B, Lindahl E. GROMACS: High performance molecular simulations through multi-level parallelism from laptops to supercomputers. SoftwareX. 2015;1:19-25.

Agarwal R, Agarwal C, Ichikawa H, Singh RP, Aggarwal BB. Anticancer potential of silymarin: from bench to bed side. Anticancer research. 2006;26(6B):4457-98.

Akey DL, Brown WC, Dutta S, Konwerski J, Jose J, Jurkiw TJ, DelProposto J, Ogata CM, Skiniotis G, Kuhn RJ, Smith JL. Flavivirus NS1 structures reveal surfaces for associations with membranes and the immune system. Science. 2014;343(6173):881-5.

Aljancić I, Stanković M, Tesević V, Vujisić L, Vajs V, Milosavljević S. Protective effect on human lymphocytes of some flavonoids isolated from two Achillea species. Natural product communications. 2010;5(5):729-32.

Anthony KP, Saleh MA. Free radical scavenging and antioxidant activities of silymarin components. Antioxidants. 2013;2(4):398-407.

Avirutnan P, Fuchs A, Hauhart RE, Somnuke P, Youn S, Diamond MS, Atkinson JP. Antagonism of the complement component $\mathrm{C} 4$ by flavivirus nonstructural protein NS1. Journal of Experimental Medicine. 2010; jem-20092545.

Blom N, Sicheritz-Pontén T, Gupta R, Gammeltoft S, Brunak S. Prediction of post-translational glycosylation and phosphorylation of proteins from the amino acid sequence. Proteomics. 2004;4(6):1633-49.

Butturini E, Cavalieri E, de Prati AC, Darra E, Rigo A, Shoji K, Murayama N, Yamazaki H, Watanabe Y, Suzuki H, Mariotto
S. Two naturally occurring terpenes, dehydrocostuslactone and costunolide, decrease intracellular GSH content and inhibit STAT3 activation. PLoS One. 2011;6(5):e20174.

Chavez ML, Chavez PI. Feverfew. Lippincott's Hospital Pharmacy. 1999; 34(4):436-61.

Choi EJ, Ahn WS. Antiproliferative effects of dehydrocostuslactone through cell cycle arrest and apoptosis in human ovarian cancer SK-OV-3 cells. International journal of molecular medicine. 2009; 23(2):211.

Choudhary MI, Jalil S, Nawaz SA, Khan KM, Tareen RB. Antiinflammatory and lipoxygenase inhibitory compounds from vitex agnus-castus. Phytotherapy Research. 2009;23(9):1336-9.

Csupor-Löffler B, Hajdú Z, Zupkó I, Réthy B, Falkay G, Forgo P, Hohmann J. Antiproliferative effect of flavonoids and sesquiterpenoids from Achillea millefolium sl on cultured human tumour cell lines. Phytotherapy Research. 2009;23(5):672-6.

Daina A, Michielin O, Zoete V. SwissADME: a free web tool to evaluate pharmacokinetics, drug-likeness and medicinal chemistry friendliness of small molecules. Scientific Reports. 2017;7:42717.

Daina A, Zoete V. A BOILED-Egg to Predict Gastrointestinal Absorption and Brain Penetration of Small Molecules. ChemMedChem. 2016;11(11):1117-21.

de Souza P, Gasparotto A, Crestani S, Stefanello MÉ, Marques MC, da Silva-Santos JE, Kassuya CA. Hypotensive mechanism of the extracts and artemetin isolated from Achillea millefolium L.(Asteraceae) in rats. Phytomedicine. 2011;18(10):819-25.

Diopan V, Babula P, Shestivska V, Adam V, Zemlicka M, Dvorska M, Hubalek J, Trnkova L, Havel L, Kizek R. Electrochemical and spectrometric study of antioxidant activity of pomiferin, isopomiferin, osajin and catalposide. Journal of pharmaceutical and biomedical analysis. 2008;48(1):127-33.

Dufall KG, Ngadjui BT, Simeon KF, Abegaz BM, Croft KD. Antioxidant activity of prenylated flavonoids from the West African medicinal plant Dorstenia mannii. Journal of ethnopharmacology. 2003;87(1):67-72.

Dzoyem JP, Hamamoto H, Ngameni B, Ngadjui BT, Sekimizu K. Antimicrobial action mechanism of flavonoids from Dorstenia species. Drug discoveries \& therapeutics. 2013;7(2):66-72. 
Iqra Qaddir, Arshia Majeed, Waqar Hussain, Sajid Mahmood, Nouman Rasool

Freedman ND, Curto TM, Morishima C, Seeff LB, Goodman ZD, Wright EC, Sinha R, Everhart JE. Silymarin use and liver disease progression in the Hepatitis C Antiviral Long-Term Treatment against Cirrhosis trial. Alimentary pharmacology \& therapeutics. 2011;33(1):127-37.

Gupta R, Brunak S. Prediction of glycosylation across the human proteome and the correlation to protein function. InPac. Symp. Biocomput 2001;20022002:310-322.

Huang B. MetaPocket: a meta approach to improve protein ligand binding site prediction. OMICS A Journal of Integrative Biology. 2009;13(4):325-30.

Humphrey W, Dalke A, Schulten K. VMD: visual molecular dynamics. Journal of molecular graphics. 1996;14(1):33-8.

Hussain K, Zia-ul-Hussnain S, Shahazad A. Distributions and folk tibb knowledge of milk thistle (Silybum marianum L.) in NWFP, Pakistan. Ethnobotanical Leaflets. 2010;2010(3):5.

Johnson M, Zaretskaya I, Raytselis Y, Merezhuk Y, McGinnis S, Madden TL. NCBI BLAST: a better web interface. Nucleic acids research. 2008;36(2):W5-9.

Kapadia GJ, Azuine MA, Tokuda H, Hang E, Mukainaka T, Nishino H, Sridhar R. Inhibitory effect of herbal remedies on 12-O-tetradecanoylphorbol-13-acetate-promoted EpsteinBarr virus early antigen activation. Pharmacological research. 2002;45(3):213-20.

Kim EJ, Hong JE, Lim SS, Kwon GT, Kim J, Kim JS, Lee KW, Park JH. The hexane extract of Saussurea lappa and its active principle, dehydrocostus lactone, inhibit prostate cancer cell migration. Journal of medicinal food. 2012;15(1):24-32.

Kuete V, Ngameni B, Wiench B, Krusche B, Horwedel C, Ngadjui BT, Efferth T. Cytotoxicity and mode of action of four naturally occuring flavonoids from the genus Dorstenia: gancaonin Q, 4-hydroxylonchocarpin, 6-prenylapigenin, and 6, 8-diprenyleriodictyol. Planta medica. 2011;77(18):1984-9.

Lani R, Hassandarvish P, Chiam CW, Moghaddam E, Chu JJ, Rausalu K, Merits A, Higgs S, Vanlandingham D, Bakar SA, Zandi K. Antiviral activity of silymarin against chikungunya virus. Scientific reports. 2015;5:11421.

Lee SK, Lee IH, Kim HJ, Chang GS, Chung JE, No KT. The PreADME Approach: Web-based program for rapid prediction of physico-chemical, drug absorption and drug-like properties. EuroQSAR 2002 Designing Drugs and Crop Protectants: processes, problems and solutions. 2003;2003:418-20.

Lindenbach BD, Rice CM. Flaviviridae: the viruses and their replication. Fields virology. 2001;1:991-1041.
Liu CY, Chang HS, Chen IS, Chen CJ, Hsu ML, Fu SL, Chen YJ. Costunolide causes mitotic arrest and enhances radiosensitivity in human hepatocellular carcinoma cells. Radiation Oncology. 2011;6(1):56.

Long C, Sauleau P, David B, Lavaud C, Cassabois V, Ausseil F, Massiot G. Bioactive flavonoids of Tanacetum parthenium revisited. Phytochemistry. 2003;64(2):567-9.

Lovell SC, Davis IW, Arendall WB, de Bakker PIW, Word JM, Prisant MG, Richardson JS, Richardson DC. Structure validation by Calpha geometry: phi,psi and Cbeta deviation. Proteins: Structure, Function \& Genetics. 2002;50:437-450.

Markham KR. Flavones, flavonols and their glycosides. Methods in plant biochemistry. 1989;1:197-235.

Marles RJ, Kaminski J, Arnason JT, Pazos-Sanou L, Heptinstall S, Fischer NH, Crompton CW, Kindack DG, Awang DV. A bioassay for inhibition of serotonin release from bovine platelets. Journal of natural products. 1992;55(8):1044-56.

Michielin EM, Salvador AA, Riehl CA, Smânia A, Smânia EF, Ferreira SR. Chemical composition and antibacterial activity of Cordia verbenacea extracts obtained by different methods. Bioresource technology. 2009;100(24):6615-23.

Mirza SB, Salmas RE, Fatmi MQ, Durdagi S. Virtual screening of eighteen million compounds against dengue virus: Combined molecular docking and molecular dynamics simulations study. Journal of Molecular Graphics and Modelling. 2016;66:99-107.

Morris GM, Huey R, Lindstrom W, Sanner MF, Belew RK, Goodsell DS, Olson AJ. AutoDock4 and AutoDockTools4: Automated docking with selective receptor flexibility. Journal of computational chemistry. 2009;30(16):2785-91.

Murphy BT, Cao S, Norris A, Miller JS, Ratovoson F, Andriantsiferana R, Rasamison VE, Kingston DG. Cytotoxic Flavanones of Schizolaena hystrix from the Madagascar Rainforest 1. Journal of natural products. 2005;68(3):417-9.

$\mathrm{N}$ Powers C, N Setzer W. An in-silico investigation of phytochemicals as antiviral agents against dengue fever. Combinatorial chemistry \& high throughput screening. 2016;19(7):516-36.

Pareek A, Suthar M, Rathore GS, Bansal V. Feverfew (Tanacetum parthenium L.): A systematic review. Pharmacognosy reviews. 2011;5(9):103.

Polyak SJ, Ferenci P, Pawlotsky JM. Hepatoprotective and antiviral functions of silymarin components in hepatitis $\mathrm{C}$ virus infection. Hepatology. 2013;57(3):1262-1271. 
Qaddir I, Rasool N, Hussain W, Mahmood S. Computeraided analysis of phytochemicals as potential dengue virus inhibitors based on molecular docking, ADMET and DFT studies. Journal of Vector Borne Diseases. 2017;54(3): 255-262.

Scaturro P, Cortese M, Chatel-Chaix L, Fischl W, Bartenschlager R. Dengue virus non-structural protein 1 modulates infectious particle production via interaction with the structural proteins. PLoS pathogens. 2015;11(11):e1005277.

Searo W. Comprehensive Guidelines for Prevention and Control of Dengue and Dengue Haemorrhagic Fever Revised and expanded.

Senthilvel P, Lavanya P, Kumar KM, Swetha R, Anitha P, Bag S, Sarveswari S, Vijayakumar V, Ramaiah S, Anbarasu A. Flavonoid from Carica papaya inhibits NS2B-NS3 protease and prevents Dengue 2 viral assembly. Bioinformation. 2013;9(18):889-95.

Shlyakhov EN, Rubinstein E. Human live anthrax vaccine in the former USSR. Vaccine. 1994;12(8):727-30.

Sridevi VK, Chouhan HS, Singh NK, Singh SK. Antioxidant and hepatoprotective effects of ethanol extract of Vitex glabrata on carbon tetrachloride-induced liver damage in rats. Natural product research. 2012;26(12):1135-40.
Su CI, Tseng CH, Yu CY, Lai MM. SUMO modification stabilizes dengue virus nonstructural protein 5 to support virus replication. Journal of virology. 2016;90(9):4308-19.

Temporão JG, Penna GO, Carmo EH, Coelho GE, Azevedo RD, Nunes MR, da Costa Vasconcelos PF. Dengue virus serotype 4, Roraima state, Brazil. Emerging infectious diseases. 2011;17(5):938.

Tran N. Blood-Brain Barrier. Encyclopedia of Clinical Neuropsychology. Springer New York. 2011.

Trott O, Olson AJ. AutoD ock Vina: improving the speed and accuracy of docking with a new scoring function, efficient optimization, and multithreading. Journal of computational chemistry. 2010;31(2):455-61.

Wagoner J, Negash A, Kane OJ, Martinez LE, Nahmias Y, Bourne N, Owen DM, Grove J, Brimacombe C, McKeating JA, Pécheur EI. Multiple effects of silymarin on the hepatitis C virus lifecycle. Hepatology. 2010;51(6):1912-21.

Whitehead SS, Blaney JE, Durbin AP, Murphy BR. Prospects for a dengue virus vaccine. Nature Reviews Microbiology. 2007;5(7):518-28.

Received for publication on $19^{\text {th }}$ July 2017 Accepted for publication on $21^{\text {st }}$ January 2019 